\title{
Ral and Phospholipase D2-Dependent Pathway for Constitutive Metabotropic Glutamate Receptor Endocytosis
}

\author{
Moshmi Bhattacharya, ${ }^{1 \star}$ Andy V. Babwah, ${ }^{1 \star}$ Christina Godin, ${ }^{1}$ Pieter H. Anborgh,,${ }^{1}$ Lianne B. Dale, ${ }^{1}$ Michael 0. Poulter,${ }^{3}$ \\ and Stephen S. G. Ferguson ${ }^{1,2}$ \\ ${ }^{1}$ Cell Biology Research Group, Robarts Research Institute, London, Ontario, Canada N6A 5K8, ${ }^{2}$ Department of Physiology and Pharmacology, University of \\ Western Ontario, London, Ontario, Canada N6A 5C1, and ${ }^{3}$ Neuroscience Research Institute, Carleton University, Ottawa, Ontario, Canada K1S 5B6
}

G-protein-coupled receptors play a central role in the regulation of neuronal cell communication. Class 1 metabotropic glutamate receptors (mGluRs) mGluR1a and mGluR5a, which are coupled with the hydrolysis of phosphoinositides, are essential for modulating excitatory neurotransmission at glutamatergic synapses. These receptors are constitutively internalized in heterologous cell cultures, neuronal cultures, and intact neuronal tissues. We show here that the small GTP-binding protein Ral, its guanine nucleotide exchange factor RalGDS (Ral GDP dissociation stimulator), and phospholipase D2 (PLD2) are constitutively associated with class 1 mGluRs and regulate constitutive mGluR endocytosis. Moreover, both Ral and PLD2 are colocalized with mGluRs in endocytic vesicles in both human embryonic kidney 293 (HEK 293) cells and neurons. Ral and PLD2 activity is required for the internalization of class $1 \mathrm{mGluRs}$ but is not required for the internalization of the $\beta_{2}$-adrenergic receptor. Constitutive class $1 \mathrm{mGluR}$ internalization is not dependent on the downstream Ral effector proteins Ral-binding protein 1 and PLD1 or either ADP-ribosylation factors ARF1 or ARF6. The treatment of HEK 293 cells and neurons with small interfering RNA both downregulates PLD2 expression and blocks mGluR1a and mGluR5a endocytosis. The constitutive internalization of mGluR1a and mGluR5a is also attenuated by the treatment of cells with 1-butanol to prevent PLD2-mediated phosphatidic acid formation. We propose that the formation of a mGluR-scaffolded RalGDS/Ral/PLD2 protein complex provides a novel alternative mechanism to $\beta$-arrestins for the constitutive endocytosis of class $1 \mathrm{mGluRs}$.

Key words: G-protein-coupled receptor; Ral GTP-binding protein; phospholipase D; endocytosis; metabotropic glutamate receptor; glutamate

\section{Introduction}

Metabotropic glutamate receptors (mGluRs) comprise a unique family of G-protein-coupled receptors (GPCRs) that is presynaptically and postsynaptically localized to modulate excitatory neurotransmission (Nakanishi, 1994; Dale et al., 2002). Class 1 mGluRs (mGluR1 and mGluR5) are coupled via $\mathrm{G} \alpha$ to the stimulation of phospholipase $\mathrm{C} \beta$. However, other than retaining the seven transmembrane spanning helices characteristic of all GPCRs, class $1 \mathrm{mGluRs}$ bear absolutely no sequence homology to prototypic GPCRs, such as the $\beta_{2}$-adrenergic receptor ( $\left.\beta_{2} \mathrm{AR}\right)$. Nevertheless, mGluR1a G-protein signaling is attenuated by the same regulatory proteins described for prototypic GPCRs (Dale et al., 2000; Sallese et al., 2000).

For the majority of GPCRs, G-protein-coupled receptor kinase phosphorylation promotes $\beta$-arrestin binding to the intra-

Received April 8, 2004; revised Aug. 18, 2004; accepted Aug. 19, 2004.

This work was supported by Heart and Stroke Foundation of Ontario Grant T4987 and Canadian Institutes of Health Research (CIHR) Grant MOP 62738 to S.S.G.F. and by CIHR Grant MOP 100765 to M.O.P. M.B. is the recipient of a CIHR fellowship, and A.V.B. is the recipient of a Canadian Hypertension Society/CIHR fellowship. S.S.G.F. is the recipient of a Premier's Research Excellence Award and Canada Research Chair in Molecular Neuroscience and is a Heart and Stroke Foundation of Ontario Career Investigator. We thank Erica Li for technical assistance.

${ }^{*} M . B$. and A.V.B. contributed equally to this work.

Correspondence should be addressed to Dr. Stephen S. G. Ferguson, Cell Biology Research Group, Robarts Research Institute, 100 Perth Drive, P.0. Box 5015, London, Ontario, Canada N6A 5K8. E-mail: ferguson@robarts.ca. DOI:10.1523/JNEUROSCI.3155-04.2004

Copyright $\odot 2004$ Society for Neuroscience $\quad$ 0270-6474/04/248752-10\$15.00/0 cellular face of the GPCR, resulting in the physical uncoupling of the receptor from heterotrimeric G-proteins (Premont et al., 1995; Ferguson, 2001). Receptor-bound $\beta$-arrestins also function as endocytic adaptor proteins that target GPCRs to clathrincoated pits for endocytosis (Ferguson et al., 1996; Goodman et al., 1996; Laporte et al., 1999). However, many GPCRs are internalized via a novel, ill-defined, $\beta$-arrestin-independent mechanism (Ferguson, 2001). Although GPCR internalization is generally considered to be an agonist-stimulated phenomenon, mGluR1 and mGluR5 exhibit constitutive endocytosis in heterologous cell cultures and primary neurons (Sallese et al., 2000; Dale et al., 2001; Fourgeaud et al., 2003; Pula et al., 2004), and both receptors are localized by electron microscopy to the intracellular compartment of postsynaptic specializations in hippocampal neurons (Hanson and Smith, 1999). The constitutive internalization of mGluR1a is reported to occur via both $\beta$-arrestin-dependent and -independent mechanisms, whereas constitutive mGluR5 internalization is proposed to be $\beta$-arrestin and clathrin independent (Dale et al., 2001; Fourgeaud et al., 2003; Pula et al., 2004).

Several recent studies have implicated a role for the small GTP-binding protein Ral in receptor-mediated endocytosis (Nakashima et al., 1999; Jullien-Flores et al., 2000; Matsuzaki et al., 2002). Ral is primarily localized to the plasma membrane but is also observed in endocytic vesicles (Feig, 2003). Ral contributes to the regulation of the clathrin-dependent endocytosis of trans- 

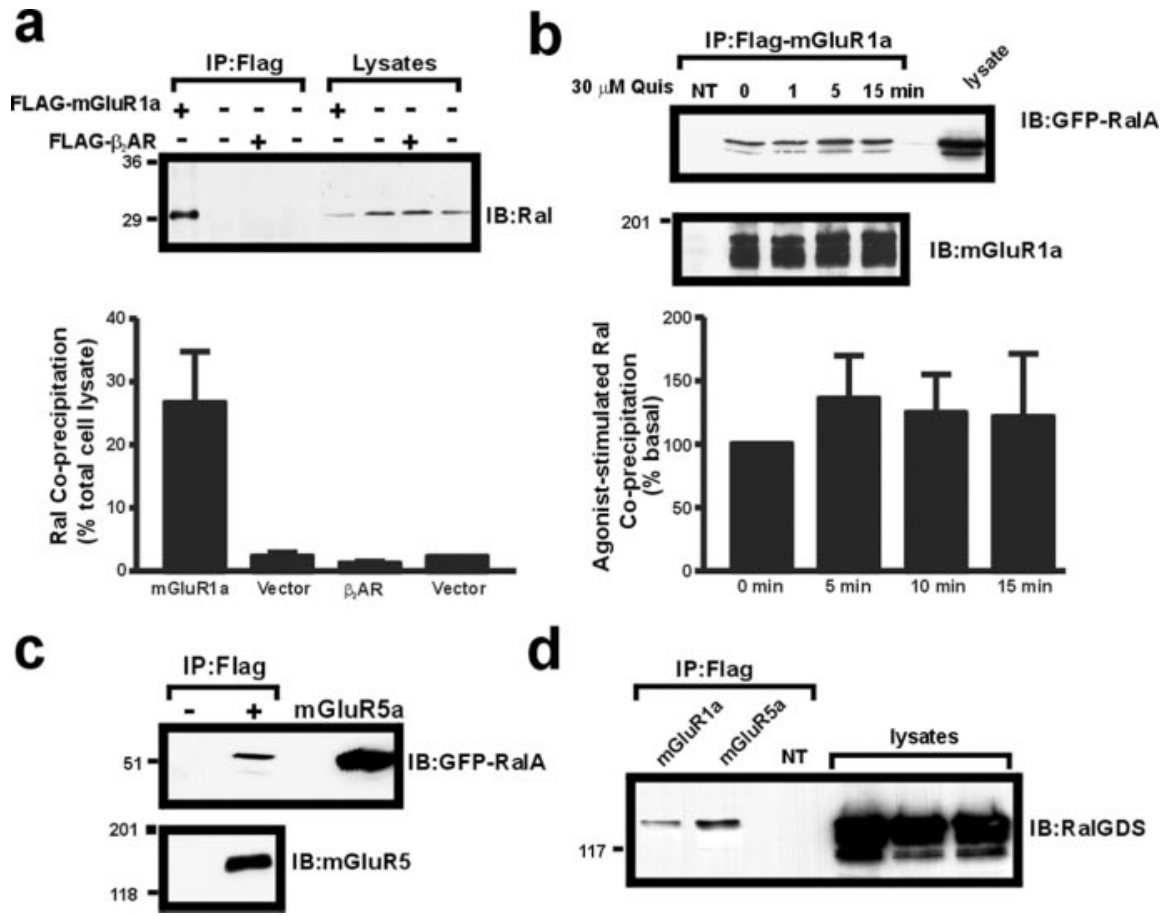

Figure 1. mGluR1a is constitutively associated with Ral and RaIGDS. HEK 293 cell lysates transiently expressing either FLAG-mGluR1a or FLAG- $\beta_{2} A R$ and GFP-RalA or GFP-RalGDS were immunoprecipitated using a monoclonal anti-FLAG antibody. $a$, Representative immunoblot showing the coimmunoprecipitation of endogenous Ral from cells coexpressing FLAG-mGluR1a $(+)$ but not in cells lacking coexpressed receptors ( - ) or expressing Flag- $\beta_{2} A R(+)$. The immunoblot is representative of three independent experiments. The bar graph shows the mean \pm SE of the amount of endogenous Ral coimmunprecipitated expressed as a percentage of total Ral expression in the cell lysate. b, Coimmunoprecipitation of GFP-RalA with FLAG-mGluR1a in the absence and presence of agonist (30 $\mu \mathrm{m}$ quisqualate) stimulation for $0-15 \mathrm{~min}$. The data shown are representative of three independent experiments, and the bar graph shows the mean \pm SE of the amount of GFP-Ral coimmunprecipitated with FLAG-mGluR1a after agonist treatment relative to that coimmunprecipitated in the absence of agonist. c, Representative immunoblot showing the coimmunoprecipitation of GFP-Ral from cells coexpressing FLAG-mGluR5a $(+)$ but not in cells lacking coexpressed receptors ( - ). The immunoblot is representative of three independent experiments. $d$, Coimmunoprecipitation of GFP-RalGDS with FLAG-mGluR1a and FLAG-mGluR5a in the presence and absence of agonist stimulation (30 $\mu \mathrm{m}$ quisqualate). The data shown are representative of three independent experiments. NT, Nontransfected. Lysates correspond to $100 \mu \mathrm{g}$ of total HEK cell lysate.

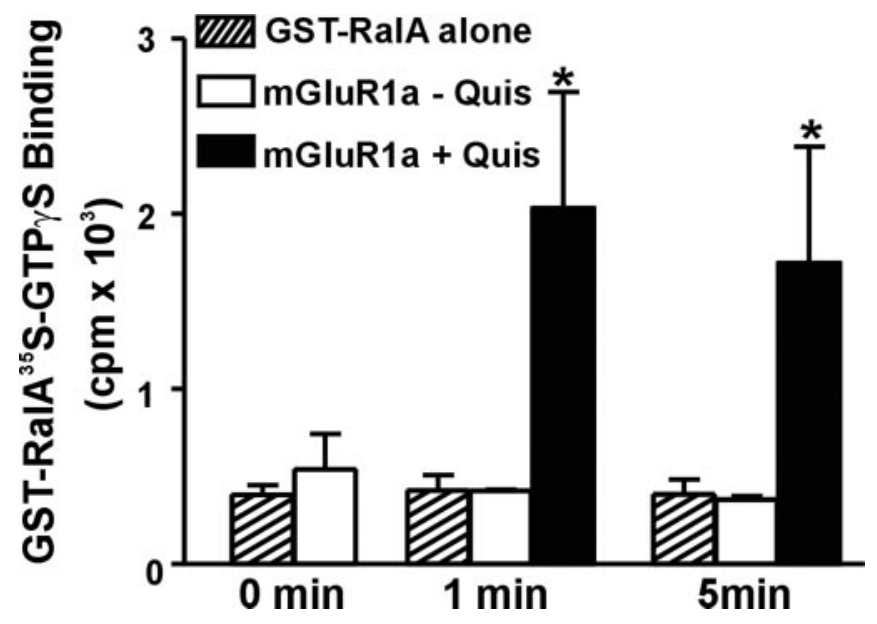

Figure 2. Agonist activation of mGluR1a stimulates Ral activity. Shown is mGluR1a stimulated binding of $\left[{ }^{35}\right.$ S]-GTP $\gamma$ S to GST-RaIA. HEK 293 cells expressing GST-RalA with either empty vector or FLAG-mGluR1a were incubated in the presence or absence of $30 \mu \mathrm{m}$ quisqualate. The results represent the mean \pm SE of six independent experiments. ${ }^{*} p<0.05$ compared with GST-RalA alone.

ferrin, activin, insulin, and epidermal growth factor (EGF) receptors via the recruitment of Ral-binding protein 1 (RalBP1), which in turn binds to the $\mu$-adaptin subunit of the heterotetrameric adaptor protein-2 (AP2) adaptor complex required for clathrin- mediated endocytosis (Nakashima et al., 1999; Jullien-Flores et al., 2000; Matsuzaki et al., 2002). Ral may also regulate EGF receptor endocytosis through its interaction with phospholipase D1 (PLD1) and PLD2 (Shen et al., 2001). However, a role for Ral in GPCR endocytosis has yet to be described, and it is not clear what functional role PLD2 plays in regulating clathrin-coated vesicle-mediated endocytosis (Shen et al., 2001; Koch et al., 2003, 2004; Du et al., 2004). Here, we show that both Ral and PLD2 bind to class 1 mGluRs and act as proximal adaptor proteins, the activity of which is specifically required to promote constitutive mGluR endocytosis.

\section{Materials and Methods}

Materials. Human embryonic kidney 293 (HEK 293) cells were from American Type Culture Collection (Manassas, VA). All cell culture media were purchased from Invitrogen (San Diego, CA), unless stated otherwise. Quisqualate was obtained from Tocris Cookson (Bristol, UK). Protein G-Sepharose beads, glutathioneSepharose beads, anti-mouse and anti-rabbitHRP antobodies, and enhanced chemiluminescence (ECL) Western blotting detection reagents were from Amersham Biosciences (Oakville, Ontario, Canada). The anti-FLAG mouse monoclonal antibody M2 and polyclonal antibodies, isoproterenol, and all other biochemical reagents were purchased from Sigma (St. Louis, MO).

DNA construction. All recombinant cDNA procedures were performed in accordance with standard protocols. Human RalGDS (Ral GDP dissociation stimulator), RalA, and mutants RalA-S28N and RalA-G23V were cloned as described previously (Bhattacharya et al., 2002). Human RalBP1 (RLIP 76) was a kind gift from Dr. Jacques Camonis (Institut Curie, Institut National de la Santé et de la Recherche Médicale, Paris, France). RLIP mutants were generated by PCR and cloned as $\mathrm{N}$-terminally $m y c$-tagged BamHI-NotI products into pcDNA3. The RLIP $\mu 2$-binding domain deletion mutant (RLIP- $\mu 2 \mathrm{BD} \Delta$ ) and RLIP $\mu 2$ binding domain (RLIP- $\mu 2 \mathrm{BD}$ ) were created by deleting nucleotides corresponding to amino acids 1-209 and 209-655, respectively. Plasmid expression vectors for human PLD1 (pCGN-hPLD1), mouse PLD2 (pCGN-mPLD2), and the catalytically inactive mutants hPLD1-K898R (pCGN-hPLD1-K898R) and mPLD2-K758R (pCGN-mPLD2-K758R) were a generous gift from Dr. Michael Frohman (State University of New York, Stony Brook, NY). hPLD1 and mPLD2 were subcloned into pEYFPN1 (Clontech, Cambridge, UK). Green fluorescent protein (GFP)clathrin light chain was a gift from Dr. James Keen (Thomas Jefferson University, Philadelphia, PA). Plasmid expression vectors for human ARF1-pcDL-SR $\alpha 296$ and bovine ARF6- pcDL-SR $\alpha 296$ and mutants (ARF1-Q67L-pcDL-SR $\alpha 296$, ARF1-T31N-pcDL-SR $\alpha 296$, ARF6-Q67LpcDL-SR $\alpha 296$, and ARF6-T27N-pcDL-SR $\alpha 296)$ were kind gifts from Dr. Harish Radhakrishna (Georgia Institute of Technology, Atlanta, GA) and were subcloned into pcDNA3.1 for expression. All constructs were sequenced by automated DNA sequencing to confirm sequence integrity.

Cell culture and transfections. HEK 293 cells were maintained in Eagle's minimal essential media (MEM) supplemented with $10 \%$ (v/v) fetal bovine serum (HyClone, Logan, UT) and $50 \mu \mathrm{g} / \mathrm{ml}$ gentamicin. The cells were seeded at a density of $2.5 \times 10^{6} / 100 \mathrm{~mm}$ dish (Falcon) and were transiently transfected by a modified calcium phosphate method (Bhattacharya et al., 2002) with the cDNA constructs described in the figure 
legends. After transfections ( $\sim 18 \mathrm{hr}$ later), the cells were re-seeded on $35 \mathrm{~mm}$ glass-bottomed culture dishes (Mattek, Ashland, MA) for confocal live cell imaging studies, or on 12-well dishes (Falcon) for internalization studies.

GTP $\mathrm{S}$ loading assays. These experiments were conducted as described previously (Bhattacharya et al., 2002). HEK 293 cells were transfected with GST-RalA with and without FLAGmGluR1a. Cells were serum starved for $2-3 \mathrm{hr}$ and then labeled with $\left[{ }^{35} \mathrm{~S}\right] \mathrm{GTP} \gamma \mathrm{S}(1 \mu \mathrm{Ci} / \mathrm{ml})$ for $30 \mathrm{~min}$ at $37^{\circ} \mathrm{C}$ in digitonin buffer $(1 \%$ digitonin, 20 mM HEPES, pH 7.5, $100 \mathrm{~mm} \mathrm{NaCl}, 5$ $\mathrm{mM} \mathrm{MgCl}$, and $1 \mathrm{~mm} \mathrm{DTT;} 0.5 \mathrm{ml} /$ well), then incubated for $7 \mathrm{~min}$ at $37^{\circ} \mathrm{C}$ with or without 30 $\mu \mathrm{M}$ quisqualate in serum-free MEM. Cells were washed twice with ice-cold PBS and lysed in cold lysis buffer containing $50 \mathrm{~mm}$ Tris, $\mathrm{pH}$ 8.0, $150 \mathrm{~mm} \mathrm{NaCl}, 1 \mu \mathrm{M}$ GTP $\gamma \mathrm{S}$, and $0.1 \%$ Triton $\mathrm{X}-100$ plus protease inhibitors, and GST-RalA was precipitated on glutathione-Sepharose 4B beads. The samples were counted for $\left[{ }^{35} \mathrm{~S}\right]$ activity (counts per minute) in a beta scintillation counter. Aliquots $(20 \mu \mathrm{l})$ of each cleared supernatant were analyzed for relative expression of GST-RalA by immunoblotting using an antiGST antibody.

Single turnover receptor internalization assays. The agonist-independent FLAG-mGluR and FLAG- $\beta_{2}$ AR (10 $\mu \mathrm{M}$ isoproterenol) internalization was measured by flow cytrometry as described previously (Dale et al., 2001). Cell surface epitope-tagged receptors were prelabeled with primary anti-mouse FLAG antibody (1:500) on ice for $45 \mathrm{~min}$. Cells were then warmed to $37^{\circ} \mathrm{C}$ either in the absence of agonist (for mGluR) or in the presence of agonist for the times indicated in the figure legends. Cells were then transferred back on ice and labeled with secondary FITC-conjugated anti-mouse IgG antibody (1:500 dilution) for $45 \mathrm{~min}$. Under these conditions, receptors are able to undergo only a single round of internalization. Receptor internalization is defined as the fraction of total cell receptors lost from the cell surface and thus is not available for labeling with the secondary antibody.

Confocal microscopy. Confocal microscopy was performed using an LSM-510 META laser scanning microscope (Zeiss, Oberkochen, Germany) using a Zeiss $63 \times$ or $100 \times$, numerical aperture 1.4 , oil immersion lens and filters with emission wavelengths of 488 and $514 \mathrm{~nm}$, as described previously (Dale et al., 2004). Primary neuronal cultures and HEK 293 cells expressing FLAG-mGluR1a, FLAG-mGluR5a, or FLAG$\beta_{2} \mathrm{AR}$, together with GFP-RalA, PLD1-yellow fluorescent protein (YFP), or PLD2-YFP (as described in the figure legends), were plated on coverslips. HEK 293 cells transiently expressing the various receptors individually were incubated for $1 \mathrm{hr}$ at $37^{\circ} \mathrm{C}$ in HEPES-buffered saline solution. Cells were then prelabeled with a 1:500 dilution of primary anti-FLAG monoclonal or polyclonal antibody (Sigma) in HEPES-buffered saline solution on ice for $45 \mathrm{~min}$ and then warmed to $37^{\circ} \mathrm{C}$ in the presence or absence of agonist as indicated in the figure legends. Cells were then fixed with $4 \%$ paraformaldehyde in PBS with $0.2 \%$ Triton X-100 for $20 \mathrm{~min}$ at room temperature and then labeled with a secondary antibody, either anti-mouse Alexa Fluor 488 (1:250) or Alexa Fluor 555 (1:500) (Molecular Probes, Eugene, OR). For live cell surface FLAG-mGluR1a or FLAGmGluR5a receptor labeling in HEK 293 cells or primary neuronal cultures, anti-FLAG monoclonal antibody was conjugated to either Alexa Fluor 488 or Alexa Fluor 555 using the Zenon Mouse IgG Labeling kit (Molecular Probes), following the manufacturer's instructions, just be- fore confocal imaging. Neuronal cells expressing cell surface FLAGmGluR5a were washed three times with HEPES-buffered saline solution and incubated on ice for $5 \mathrm{~min}$ before labeling on ice for $5 \mathrm{~min}$ with Alexa Fluor-tagged FLAG antibody diluted 1:1000 in HEPES-buffered saline solution. Subsequently, the cells were washed with warm HEPESbuffered saline solution to remove any unbound antibody. For experiments with butanol, cells were pretreated with 1\% 1-butanol or isobutanol for $45 \mathrm{~min}$ before labeling the receptor. Transferrin receptor labeling in HEK 293 cells was done using human transferrin conjugated to Alexa Fluor 555 (Molecular Probes), following the manufacturer's instructions, just before live confocal imaging.

Primary neuronal cell culture, immunostaining, and transfection. Neuronal cultures were prepared from either the cerebellum or cortex of embryonic day 20 rat embryos. All animal procedures were approved by the University of Western Ontario Animal Care Committee. Cells were plated on poly-L-lysine-coated $50 \mathrm{~mm}$ glass coverslips in isolation media for $5 \mathrm{hr}$ at $37^{\circ} \mathrm{C}$ and $5 \% \mathrm{CO}_{2}$ in a humidified incubator to permit cell attachment. Isolation media was subsequently replaced with serum-free culture media, and the cells were cultured for up to $21 \mathrm{~d}$ in vitro (DIV) with media replenishment every $3 \mathrm{~d}$. Isolation media consisted of MEM with Earle's salts supplemented with $2 \mathrm{~mm}$ glutamine, $10 \%$ heatinactivated horse serum, $6 \mathrm{mg} / \mathrm{ml}$ glucose, $0.5 \mathrm{U} / \mathrm{ml}$ penicillin, $0.5 \mu \mathrm{g} / \mathrm{ml}$ streptomycin, $10 \mu \mathrm{m} \mathrm{MK}-801$, and $25 \mathrm{~mm} \mathrm{KCl}$. Culture media consisted 

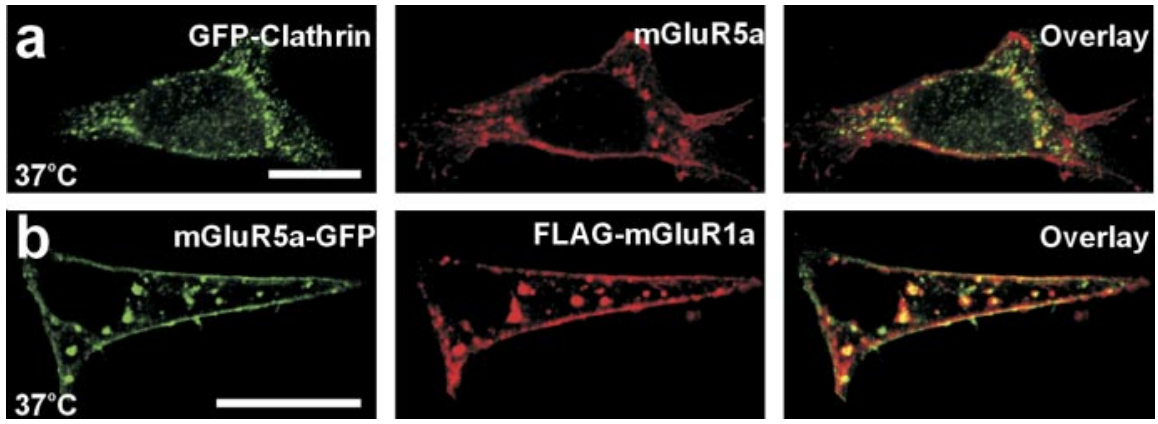

Figure 4. Colocalization of mGluR5a with clathrin and mGluR1a in HEK 293 cells. a, Representative laser scanning confocal micrograph showing the colocalization (yellow) of FLAG-mGluR5a labeled with Alexa Fluor 555-conjugated monoclonal FLAG antibody (red) with GFP-clathrin (green). Cell surface-labeled receptors were allowed to endocytose for 20 min at $37^{\circ} \mathrm{C} . b$, Representative laser scanning confocal micrograph showing the colocalization (yellow) ofFLAG-mGluR1a labeled with Alexa Fluor 555-conjugated monoclonal FLAG antibody (red) with mGluR5a-GFP (green). Cell surface-labeled receptors were allowed to endocytose for $20 \mathrm{~min}$ at $37^{\circ} \mathrm{C}$. Scale bars, $10 \mu \mathrm{m}$

of Neurobasal media supplemented with B-27, $0.5 \mathrm{U} / \mathrm{ml}$ penicillin, 0.5 $\mu \mathrm{g} / \mathrm{ml}$ streptomycin, $10 \mu \mathrm{m} \mathrm{MK}-801,25 \mathrm{~mm} \mathrm{KCl}$, and $5 \mathrm{pg} / \mathrm{ml}$ glialderived neurotrophic factor. Before experimentation, neurons were washed three times with HEPES-buffered saline solution, and all experiments were performed using HEPES-buffered saline solution, which does not contain glutamate.

Primary neuronal cultures, 4-21 DIV, were immunostained for endogenous proteins according to Craven et al. (1999), with minor modifications. Briefly, cells cultured on $50 \mathrm{~mm}$ glass coverslips were fixed in methanol at $-20^{\circ} \mathrm{C}$ for $10 \mathrm{~min}$. After fixation, cells were washed with PBS containing $0.3 \%$ Triton X-100 and 3\% BSA (PBS-T-BSA). Cells were incubated in diluted primary antibody overnight at $4^{\circ} \mathrm{C}$, followed by washes in PBS-T-BSA. Cells were then incubated in diluted fluorescent secondary antibody at room temperature for $60 \mathrm{~min}$. Coverslips were mounted in IMMU-MOUNT (Thermo Shandon, Pittsburgh, PA) onto glass slides and allowed to air dry before viewing. The primary antibodies anti-RalA (1:300) and anti-mGluR5a (1:200) were obtained from BD Biosciences (Franklin Lake, NJ) and Upstate Biotechnology (Lake Placid, NY), respectively. The secondary antibodies Alexa Fluor anti-mouse and anti-rabbit 488 and 555 were obtained from Molecular Probes. Primary neuronal cultures 4-6 DIV were transfected using Effectene (Qiagen, Hilden, Germany) following the manufacturer's instructions.

Coimmunoprecipitation. Coimmunoprecipitation of endogenous proteins from whole-brain extracts was performed using adult rat brains. Rat brains were homogenized on ice in a modified radioimmunoprecipitation assay buffer ( $150 \mathrm{~mm}$ sodium chloride, $50 \mathrm{~mm}$ Tris, $\mathrm{pH} 7.5,0.5 \%$ deoxycholate, $1 \%$ Triton X-100, 1\% NP-40, 10 mm sodium fluoride, and
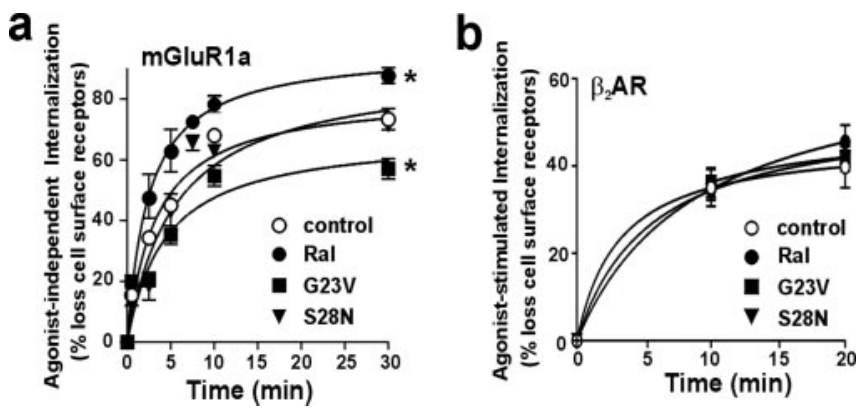

Figure 5. Effect of Ral on receptor internalization. Time courses for the agonist-independent internalization of FLAG-mGluR1a ( $a$ ) and agonist-stimulated FLAG- $\beta_{2}$ AR internalization (10 $\mu \mathrm{m}$ iosproterenol) (b) in the absence (control) or presence of RalA, RalA-S28N, or RalA-G23V. Internalization was calculated as the percentage of loss of cell surface immunofluorescence and measured by flow cytometry. HEK 293 cells were transiently transfected with $5 \mu \mathrm{g}$ of receptor plasmid CDNA and either $5 \mu \mathrm{g}$ of empty vector or RalA pcDNA3.1, RalA-S28N pcDNA3.1, or RalA-G23V pcDNA3.1 plasmid cDNAs. The data represent the mean $\pm S E$ of four to six independent experiments. ${ }^{*} p<0.05$ compared with control.
$10 \mathrm{~mm}$ sodium pyrophosphate) in the presence of protease inhibitors. mGluR 1 and mGluR5 were immunoprecipitated from whole rat brain supernatant (250 $\mu \mathrm{g}$ total protein) using 1:150 dilution of polyclonal antibodies specific for each receptor subtype (Upstate Biotechnology). Coimmunoprecipitation experiments were also performed using $500 \mu \mathrm{g}$ of total cell lysate protein solubilized from HEK 293 cells transiently transfected with the various cDNA constructs as described in the figure legends. The cells were solubilized in lysis buffer $(25 \mathrm{~mm}$ HEPES, pH 7.5, $300 \mathrm{~mm} \mathrm{NaCl}, 1.5 \mathrm{~mm} \mathrm{MgCl}_{2}$, 0.2 mM EDTA, and $0.1 \%$ Triton X-100) with protease inhibitors. FLAG-mGluRla and FLAG-mGluR5a were immunoprecipitated with a monoclonal anti-FLAG (M2) antibody (Sigma) using protein G-Sepharose (Amersham Biosciences) beads from cell lysates. The coprecipitated proteins were subjected to SDSPAGE, followed by electroblotting onto nitrocellulose membranes for immunoblotting. Immunoblots were visualized by chemiluminescence using an ECL kit (Amersham Biosciences).

Synthesis of PLD2 small interfering RNAs and transfections. Four chemically synthesized and pooled 19 nucleotide small interfering RNA (siRNA) duplexes corresponding to the human PLD2 cDNA sequences (GenBank accession number NM_002663) were purchased from Dharmacon Research (Layayette, CO) using the SMARTpool service option. The four human PLD2 sequences that were chosen for performing PLD2 RNA interference targeting were GGACAACCAAGAAGAAATA, GGACCGGCCTTTCGAAAT, GACCTGCACTACCGACTGA, and CAGCATGGCGGGACTATAT. One hundred nanomoles of the siRNA duplex was transiently cotransfected into HEK 293 cells and primary neuronal cultures with either FLAG-mGluR1a or FLAG-mGluR5a using Lipofectamine 2000. Forty-eight and $72 \mathrm{hr}$ later, cells were harvested and used for both reverse transcription (RT)-PCR analysis and FLAGmGluRla receptor internalization studies performed by either flow cytometry or confocal microscopy.

Quantification of mGluR endocytosis by confocal microscopy. Confocal images were acquired digitally $30 \mathrm{sec}$ apart over a $30 \mathrm{~min}$ period using LSM software. Images were quantified using Northern Eclipse version 6.0 software (Empix Imaging, Mississauga, Ontario, Canada) according to the manufacturer's instructions. To quantify internalization of FlagmGluRs labeled with Alexa Fluor 555 (see above for details), the image of each individual cell at $t=0$ and $t=30$ min was converted to a gray scale, and each image was threshold from 74 to 255 to measure receptor fluorescence (expressed as pixels) inside the cell. The number of pixels measured was expressed as a percentage of the total cell area for each cell (pixels/square micrometer). This process was repeated for each pair of images, and values obtained for each cell were averaged.

Data analysis. The mean $\pm \mathrm{SE}$ is shown for the values obtained for the number of independent experiments, indicated in the figure legends. Data were analyzed for statistical significance using Prism software (Graph Pad, San Diego, CA). Statistical significance was determined using an unpaired two-tailed $t$ test and also by ANOVA.

\section{Results}

\section{Ral regulates constitutive $\mathrm{mGluR}$ internalization}

Because Ral was recently demonstrated to play a role in tyrosine kinase, transferrin, and activin receptor endocytosis (Nakashima et al., 1999; Jullien-Flores et al., 2000; Matsuzaki et al., 2002), we have tested the hypothesis that Ral may bind to mGluRs and function as an endocytic adaptor protein required for the constitutive internalization of mGluR1 and mGluR5. We found that endogenous Ral is efficiently coimmunoprecipitated with FLAGmGluR1a, but not with FLAG- $\beta_{2}$ AR, in HEK 293 cells (Fig. 1a). Endogenous Ral protein $(28 \pm 8 \%)$ is associated with FLAGmGluR1a in HEK 293 cells. The formation of mGluR1a/Ral com- 
plexes appears to be agonist independent because the treatment of cells with $30 \mu \mathrm{M}$ quisqualate does not increase the amount of Ral coimmunoprecipitated with FLAGmGluR1a (Fig. 1b). GFP-RalA is also coimmunoprecipitated with FLAGmGluR5a in HEK 293 cells (Fig. 1c). In addition to Ral, the guanine nucleotide exchange factor for Ral, RalGDS, is also coimmunoprecipitated with both FLAGmGluR1a and FLAG-mGLuR5a (Fig. 1d). Consistent with the observation that both Ral and RalGDS are complexed to class 1 mGluRs, we found that mGluRla activation by agonist increases Ral GDP-forGTP exchange as demonstrated by a 3.7fold increase in $\left[{ }^{35} \mathrm{~S}\right] \mathrm{GTP} \gamma \mathrm{S}$ binding to GST-RalA (Fig. 2). However, we do not have evidence that the activation of this complex by mGluRs is required to mediate agonist-independent constitutive mGluR endocytosis.

To address the relevance of the potential interaction between class 1 mGluRs and Ral, we examined whether constitutively internalized FLAG-mGluR1a colocalizes with either GFP-RalA or endogenous Ral in endocytic vesicles. When FLAG-mGluR1a expressing HEK 293 cells are labeled on ice with Alexa Fluor 555conjugated FLAG antibody for $30 \mathrm{~min}$, FLAG-mGluR1a staining is localized to the cell surface and GFP-RalA fluorescence is localized both at the cell surface and in intracellular vesicular structures (Fig. 3a). When cells are warmed to $37^{\circ} \mathrm{C}$ for $20 \mathrm{~min}$, we observe extensive colocalization between internalized FLAGmGluRla and both GFP-RalA and endogenous Ral in intracellular vesicles (Fig. 3b,c). FLAG-mGluR5a also colocalizes with GFP-RalA in intracellular vesicles (Fig. $3 d$ ). In contrast, although agonist stimulation for $30 \mathrm{~min}$ with $10 \mu \mathrm{M}$ isoproterenol leads to the internalization of $\beta_{2} \mathrm{ARs}$, internalized $\beta_{2} \mathrm{ARs}$ are localized to intracellular vesicles and exhibit limited colocalization with GFP-RalA (Fig. 3e). Consistent with a previous report that transferrin receptor internalized via a Ral-dependent pathway (Jullien-Flores et al., 2000), we found that transferrin receptors are extensively colocalized with GFP-RalA in vesicles in HEK 293 cells (Fig. 3f).

A previous study reported that mGluR5 may be constitutively internalized via a clathrin-independent mechanism (Fourgeaud et al., 2003), whereas the constitutive internalization of mGluRla appears to be mediated by a clathrin-dependent pathway (Dale et al., 2001; Pula et al., 2004). We found that mGluR5a is colocalized with GFP-clathrin in HEK 293 cells (Fig. 4a) and that mGluR1a and mGluR5a-GFP are internalized in the same endocytic vesicles (Fig. 4b). Thus, in our studies, mGluRla and mGluR5a appear to be using the same endocytic pathway. We have shown previously that mGluRla and the $\beta_{2} \mathrm{AR}$ are internalized in the same vesicles in HEK 293 cells (Dale et al., 2001). Thus, the lack of lysates.
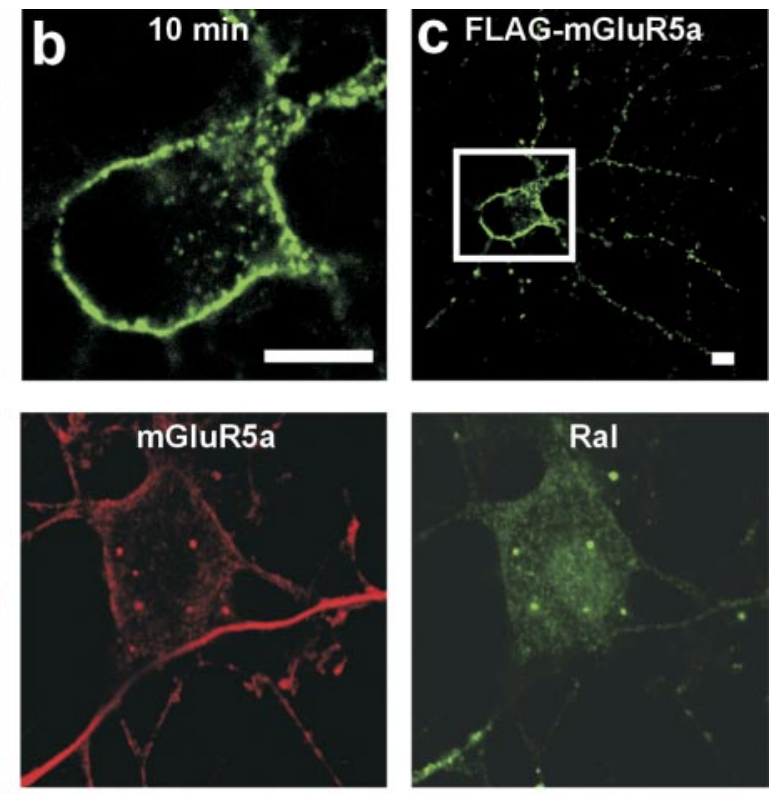

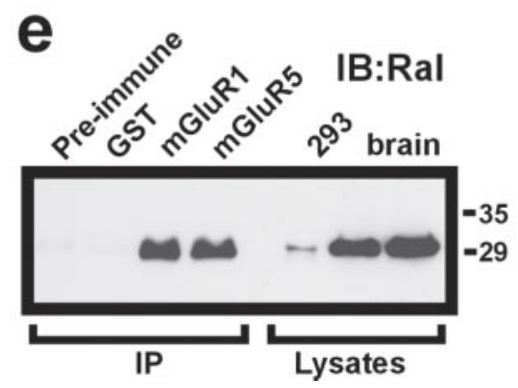

Figure 6. Localization of constitutively internalized mGluRs with Ral in intracellular vesicles in rat neurons. $a$, Shown is a conjugated FLAG antibody from the inset in c before warming the cell to $37^{\circ} \mathrm{C}(0 \mathrm{~min}) . b$ shows the agonist-independent internalization of FLAG-mGluR5a into the intracellular vesicle structure after warming the cell to $37^{\circ} \mathrm{C}$ for $10 \mathrm{~min}$. c shows a lower-field and dendrites of the cultured neuron. $d$, Shown are representative confocal images demonstrating the colocalization (yellow of endogenous mGluR5 (red) and endogenous Ral (green) in intracellular vesicles in a cortical neuron. Cells were fixed, antibodies (anti-mouse Alexa Fluor 488 and anti-rabbit Alexa FluoR 555, respectively) e Coimmunoprecipitation of endogenous Ral with endogenous mGluR1 and mGluR5 from whole-brain lysates ( $250 \mu \mathrm{g}$ of total protein) using polyclonal anti-mGluR1 and anti-mGluR5 antibodies. Polyclonal rabbit anti-GST antibody and preimmune sera were used as negative controls. Endogenous expression of Ral is shown in lysates corresponding to $100 \mu \mathrm{g}$ of HEK 293 cell protein and $50 \mu \mathrm{g}$ of protein from whole-brain

GFP-RalA localized with the $\beta_{2} \mathrm{AR}$ in vesicles suggests that $\mathrm{Ral}$ is internalized as a complex with mGluR1 and mGluR5.

To determine whether Ral activity is required for the constitutive endocytosis of mGluRla, we tested the effect of overexpressing wild-type RalA, a GTP-binding defective mutant (RalAS28N), or a GTP hydrolysis-deficient mutant (RalA-G23V) on the agonist-independent loss of cell surface FLAG-mGluR1a in HEK 293 cells. Overexpression of wild-type RalA increases both the rate and extent of constitutive FLAG-mGluRla internalization (Fig. 5a). In contrast, constitutive FLAG-mGluRla internalization is significantly reduced by Ral-G23V overexpression but is unaffected by the overexpression of RalA-S28N (Fig. 5a). These results are similar to what was previously observed for the effects of Ral mutant overexpression on EGF receptor internalization (Jullien-Flores et al., 2000) and suggest that Ral GDP-for-GTP exchange rather than GTP binding is essential for the Ralregulated endocytosis. It is unlikely that the effect of RalA-G23V 
expression on constitutive mGluRla internalization is the consequence of a general blockade of endocytosis because $\beta_{2} \mathrm{AR}$ internalization is not affected by the overexpression of RalA mutant proteins (Fig. 5b).

\section{Localization of Ral with mGluR5 in neurons}

To confirm that mGluRs are constitutively endocytosed in neurons, primary cerbellar neurons were transfected to express FLAG-mGluR5a and labeled with Alexa Fluor 488-conjugated FLAG antibody on ice and warmed to $37^{\circ} \mathrm{C}$ to allow endocytosis. At $4^{\circ} \mathrm{C}$, Alexa Fluor 488 -conjugated FLAG antibody labeling of FLAG-mGluR5a is limited to the plasma membrane of the cell body (Fig. $6 a$ ), but when cells are warmed to $37^{\circ} \mathrm{C}$ to allow endocytosis, extensive FLAG-mGluR5a internalization is observed in the neuronal cell body (Fig. 6b) and the dendritic arborization of cerebellar neurons (Fig. 6c). Identical results are obtained for neurons transfected with FLAG-mGluRla (data not shown). Endogenous mGluR5 and Ral proteins also colocalize in intracellular vesicular structures in the cell bodies of primary cortical neuronal cultures (Fig. 6d). Endogenous Ral protein also coimmunoprecipitates with endogenous mGluR1 and mGluR5 from whole rat brain lysates (Fig. 6e). Taken together, our data demonstrate that constitutive mGluR internalization occurs in both primary neurons and HEK 293 cells, that endogenous Ral is colocalized with mGluR5 in primary neuronal cultures, and that endogenous Ral can be coimmunoprecipitated with endogenous mGluR1 and mGluR5 from rat brain.

\section{PLD2 regulates constitutive mGluR endocytosis}

Ral contributes to the internalization of insulin, EGF, and transferrin receptors by recruiting the downstream effector protein RalBP1 (Nakashima et al., 1999; Shen et al., 2001; Matsuzaki et al., 2002), which in turn binds directly to the $\mu 2$ subunit of the AP2 adaptor complex (Jullien-Flores et al., 2000). We examined whether a series of RalBP1 mutants comprising only the $\mu 2$ adpatin-binding domain or lacking either the $\mu 2$-adaptin or the Ral-binding domains might block the constitutive internalization of FLAG-mGluR1a (Fig. 7a). We found that none of the RalBP1 mutants have any statistically significant effect on the constitutive FLAG-mGluR1a internalization when overexpressed in HEK 293 cells (Fig. 7b). Consistent with this observation, we found that RalBP1 does not coimmunoprecipitate with FLAG-mGluRla (Fig. 7c).

Two PLD isozymes have been identified, PLD1 and PLD2. PLD1 activity is regulated by the ADP-ribosylation factors (ARFs) ARF1 and ARF6 and by Ral (Kim et al., 1998; Luo et al., 1998; Chavrier and Goud, 1999). PLD2 is also activated by ARF proteins, but it is unclear whether Ral contributes to PLD2 regulation (Koch et al., 2003). PLD1 and PLD2 are associated with the EGF receptor, and PLD inhibitors block agonist-stimulated EGF, $\delta$-opioid, and angiotensin receptor internalization (Slaaby et al., 1998; Shen et al., 2001; Koch et al., 2003, 2004; Du et al., 2004). Therefore, we examined whether the expression of wild-type and mutant ARF1, ARF6, PLD1, and PLD2 proteins might augment or antagonize constitutive mGluR1a internalization. The overexpression of wild-type ARF1, dominant-negative ARF1-T31N, and constitutively active ARF1-Q67L have no statistically significant effect on constitutive FLAG-mGluRla endocytosis (Fig. $8 a)$, and ARF1 does not coimmunoprecipitate with mGluRla (Fig. $8 b$ ). Although ARF6 regulates the endocytosis of the $\beta_{2} \mathrm{AR}$ (Claing et al., 2001), the overexpression of wild-type and mutant ARF6 proteins does not alter constitutive mGluR1a internalization, and ARF6 does not coimmunoprecipitate with FLAG- a

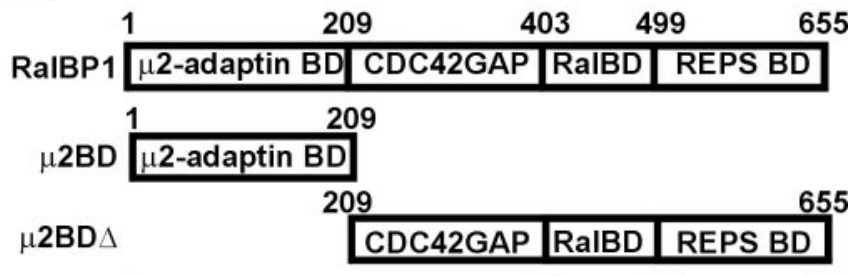
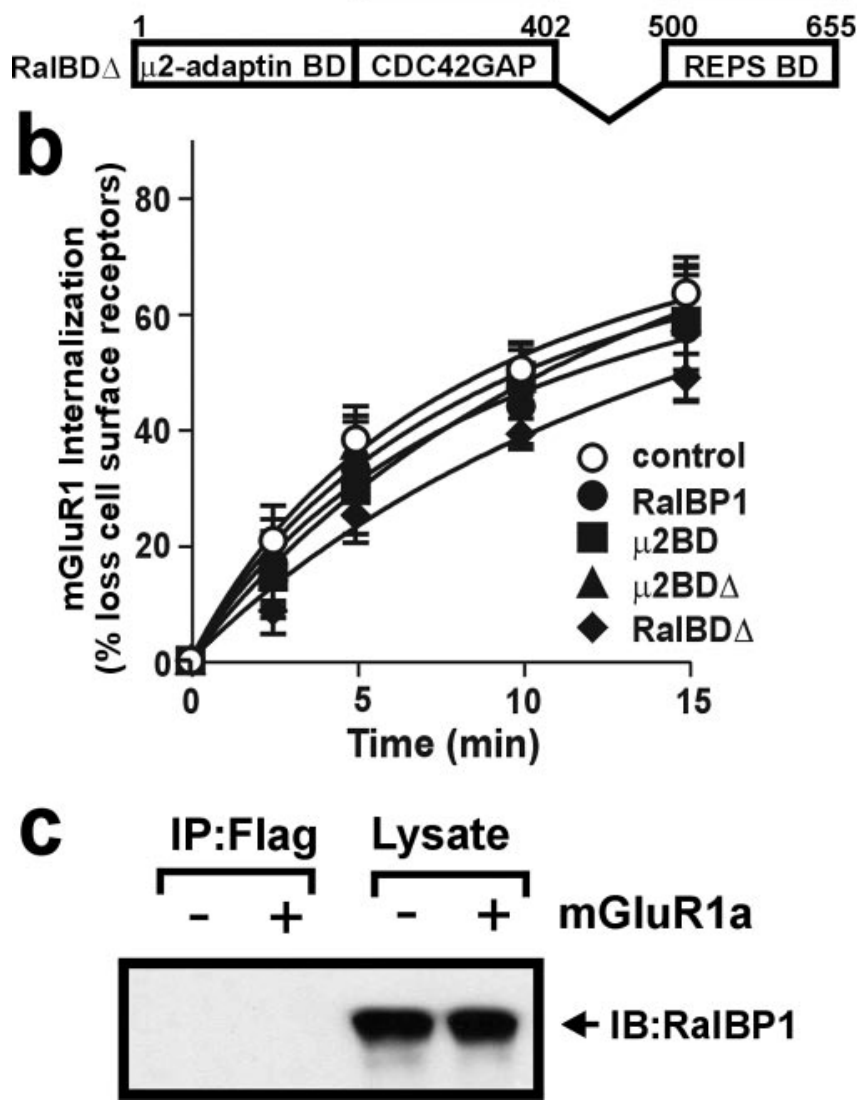

Figure 7. Effect of RalBP1 on the constitutive mGluR1a internalization. $a$, A schematic representation of various RalBP1 truncation/deletion mutants. $b$, Time course for constitutive FLAG-mGluR1a internalization in the absence (control) and presence of wild-type RaIBP1 or RalBP1 truncation/deletion mutants. HEK 293 cells were transiently transfected with $7 \mu \mathrm{g}$ of FLAG-mGluR1a and $7 \mu \mathrm{g}$ of empty vector or myc epitope-tagged RaIBP1, $\mu 2 \mathrm{BD}, \mu 2 \mathrm{BD} \Delta$, or RalBD $\Delta$ pcDNA3.1 plasmid CDNAs. The data represent the mean $\pm S E$ of five independent experiments. c, Representative immunoblot demonstrating the lack of coimmunoprecipitation of RalBP1 with FLAG-mGluR1a in $500 \mu \mathrm{g}$ of total protein from cell lysates. Lysates were immunoprecipitated using a monoclonal anti-FLAG antibody. myc-RalBP1 expression is shown in the corresponding cell lysates (100 $\mu \mathrm{g}$ of total protein). The data shown are representative of four independent experiments. BD, Binding domain.

mGluR1a (Fig. $8 c, d$ ). Constitutive mGluR1a endocytosis is unaffected by the expression of either wild-type PLD1 or a catalytically inactive PLD1-K898R mutant, and similar to what we observed for both ARF1 and ARF6, PLD1 does not coimmunoprecipitate with mGluR1a (Fig. 8e,f). Consistent with the lack of association of PLD1 with mGluR1a and the inability of PLD1 to alter constitutive mGluR1a internalization, PLD1-YFP does not colocalize with internalized FLAG-mGluR1a in HEK 293 cells (Fig. 8g). In contrast, the expression of either wild-type PLD2 or a catalytically inactive PLD2-K758R mutant significantly attenuates the constitutive FLAG-mGluR1a endocytosis (Fig. 9a). Again, this effect does not appear to be attributable to a universal blockade of clathrin-coated vesicle-mediated endocytosis because agonist- 
stimulated $\beta_{2} \mathrm{AR}$ internalization is not antagonized by either wild-type PLD2 or PLD2-K758R expression (Fig. 9b). PLD2 coimmunoprecipitates with FLAGmGluR 1a from HEK 293 cells (Fig. 9c), but agonist treatment does not increase the relative amount of PLD2 that coimmunprecipitates with the receptor (Fig. 9d). Thus, Ral, its guanine nucleotide exchange factor (RalGDS), and PLD2 are all associated in a complex with mGluRla, suggesting that the mGluRs function as a scaffold for the recruitment and activation of a RalGDS/Ral/PLD2 effector complex.

Because the overexpression of either wild-type PLD2 or PLD2-K758R attenuated constitutive mGluRla internalization, we examined the subcellular localization of PLD2-YFP. In the absence of FLAG-mGluRla expression, the majority of PLD2-YFP is associated with the plasma membrane (data not shown). However when coexpressed with FLAG-mGluRla, PLD2-YFP colocalizes with FLAGmGluRla in intracellular vesicles that are predominantly associated with and/or retained close to the plasma membrane surface of the cell, even when allowed to endocytose for $60 \mathrm{~min}$ (Fig. 9e). PLD2-YFP and FLAG-mGluR1a labeled with Alexa Fluor 555-conjugated FLAG antibody are also colocalized in vesicles that are retained at the cell surface of a Purkinje neuron cell body (Fig. 9f). Thus, it appears that PLD2 overexpression allows the redistribution of mGluRs into clathrin-coated vesicles (Dale et al., 2001) but prevents the dissociation of the vesicles from the plasma membrane, thereby impairing mGluR1a endocytosis. These observations are consistent with the data from the internalization studies (Fig. 9a). PLD2 is normally expressed at low levels in cells (Koch et al., 2003), and we propose that after overexpression, the enzyme may compete for an effector protein that must normally associate with receptor-bound PLD2. Because of the low level of endogenous PLD2 expression, we were unable to examine the colocalization of endogenous PLD2 protein with mGluRs in either HEK 293 cells or primary Purkinje neuronal cultures.

\section{PLD2 activity is required for constitutive mGluR1a endocytosis}

To determine whether endogenous PLD2 is essential for constitutive mGluR1a internalization, we prepared siRNA targeting human PLD2. Transfection of HEK 293 cells with PLD2 siRNA, but not scrambled siRNA, results in a significant reduction in PLD2 mRNA levels 48 and $72 \mathrm{hr}$ after transfection as determined by RT-PCR (Fig. 10a). Actin RT-PCR is used as a control (Fig. $10 a)$. Similarly, constitutive FLAG-mGluRla endocytosis is reduced by $81 \pm 12 \%$ and $79 \pm 28 \%$ at 48 and $72 \mathrm{hr}$ after transfection, respectively, with PLD2 siRNA, but not with scrambled siRNA (Fig. 10b). Phosphatidic acid is produced by PLDs and functions as an intracellular second messenger that is thought to be involved in vesicular trafficking (De Camilli et al., 1996). PLDs
C

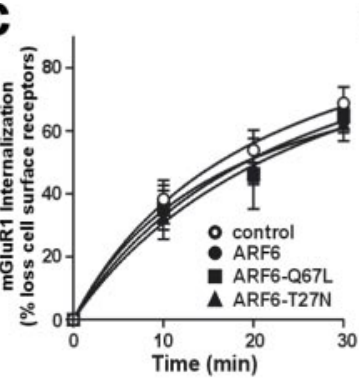

e

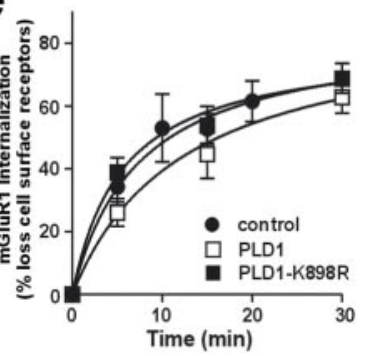

d

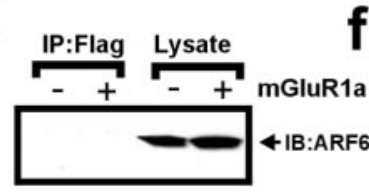

f
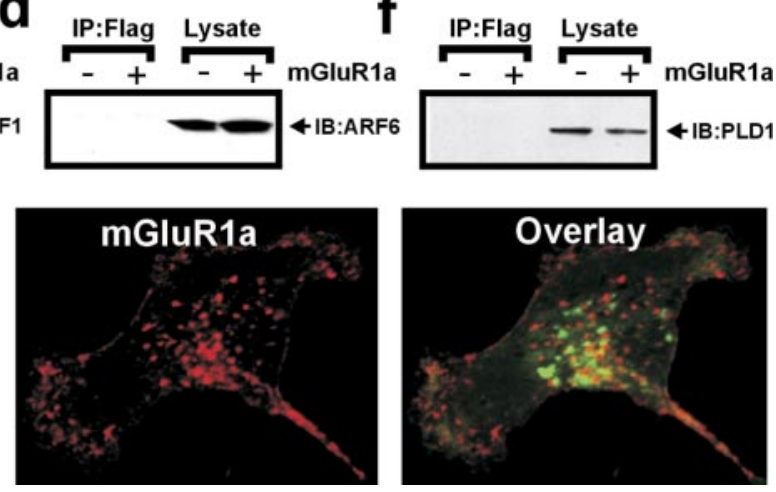

Figure 8. Effect of ARF1, ARF6, and PLD1 on the constitutive mGluR1a internalization. $a$, The effect of overexpressing wildtype, constitutively active (Q67L), and dominant-negative (T31N) ARF1 protein on constitutive FLAG-mGluR1a internalization in EK 293 cells. b, Representative immunoblot showing the lack of coimmunoprecipitation of ARF1 with FLAG-mGluR1a from HEK (27) ARF6 protein on ation data represent the mean $\pm S E$ of five independent experiments, and the coimmunoprecipitiation experiments were repeated on three independent occasions from $500 \mu \mathrm{g}$ of HEK 293 cell lysate. g, Representative confocal micrographs 作 to $100 \mu \mathrm{g}$ of total HEK cell lysate. Scale bar, $10 \mu \mathrm{m}$.

use primary alcohols (e.g., 1-butanol), but not secondary alcohols (e.g., 2-butanol), as a preferential substitute for water to generate phosphatidylalcohol instead of phosphatidic acid (Morris et al., 1997). Consequently, the treatment of cells with 1-butanol results in the inhibition of PLD-mediated cellular functions that are dependent on phosphatidic acid formation (Morris et al., 1997). Treatment of HEK 293 cells with 1\% 1-butanol (a concentration of 1-butanol that blocks phosphatidic acid production and is not toxic to the cells) (Koch et al., 2003), but not 2-butanol, inhibits constitutive mGluR1a endocytosis by $64 \pm 12 \%$ (Fig. 10c). To examine whether PLD activity is required for constitutive mGluR internalization in neurons, we transfected primary cerebellar neurons with FLAG-mGluR5a and treated the cells with either butanol or iso-butanol. We found that 2-butanol treatment did not prevent the internalization of Alexa Fluor 555-conjugated FLAG antibody-labeled cell surface FLAG-mGluR5a, whereas 1-butanol treatment prevented the internalization of cell surface-labeled FLAG-mGluR5 (Fig. 10d). Similarly, treatment of FLAG-mGluR5a transfected cerebellar neurons with PLD2 siRNA but not scrambled siRNA prevented the internalization of cell surface antibody-labeled FLAGmGluR5a (Fig. 10e). Identical results were obtained with FLAGmGluRla-transfected neurons (data not shown). Consequently, 
a
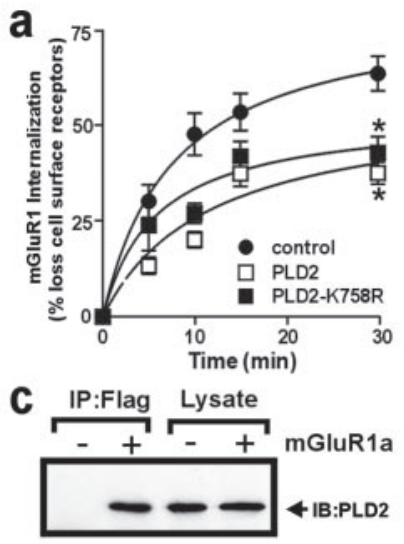

b

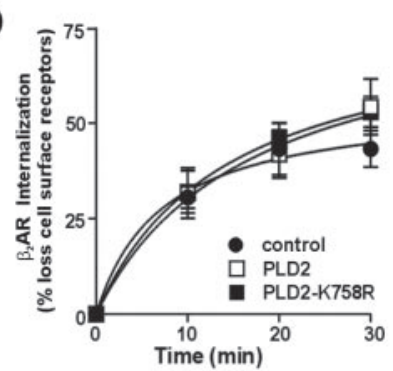

d

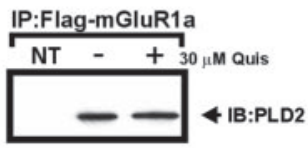

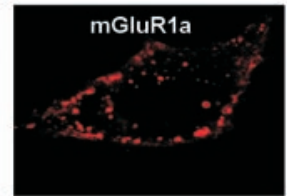

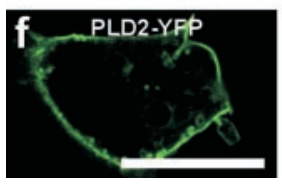

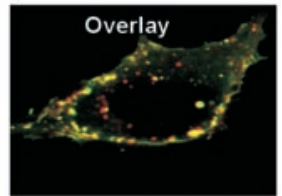

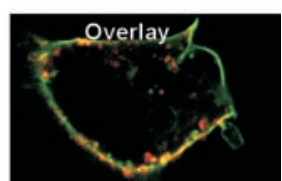

Figure 9. Effect of PLD2 on the constitutive mGluR1a internalization. Shown is the effect of overexpressing wild-type PLD2 and a catalytically inactive (K758R) PLD2 mutant on constitutive FLAG-mGluR1a internalization ( $a$ ) and agonist-stimulated FLAG- $\beta_{2} A R$ (10 $\mu \mathrm{m}$ isoproterenol) internalization $(b)$ in HEK 293 cells. The data represent the mean \pm SE of five and six independent experiments, respectively. ${ }^{*} p<0.05$ compared with control. c, Representative immunoblot demonstrating the coimmunoprecipitation of hemagglutinin (HA)-PLD2 with FLAGmGluR1a from $500 \mu \mathrm{g}$ of HEK 293 cell lysate. The data are representative of four independent experiments. $d$, Representative immunoblot showing the effect of agonist stimulation (30 $\mu \mathrm{m}$ quisqualate; $5 \mathrm{~min}$ ) on the coimmunoprecipitation of HA-PLD2 with FLAG-mGluR1a from 500 $\mu \mathrm{g}$ of HEK 293 cell lysate. The data are representative of three independent experiments. Shown are representative live cell confocal micrographs demonstrating the colocalization between FLAG-mGluR1a (red) and PLD2-YFP (green) in HEK 293 cells ( $e$ ) and in soma of a primary cerebellar neuron $(f)$ after the constitutive internalization of Alexa Fluor 555-conjugated antibody-labeled FLAG-mGluR1a for $60 \mathrm{~min}$ at $37^{\circ} \mathrm{C}$. The confocal image is taken at an image plane that transects through the cell body. Scale bars, $10 \mu \mathrm{m}$.

both PLD2 catalytic activity and phosphatidic acid production appear to be essential for constitutive mGluR1 and mGluR5 internalization in both HEK 293 cells and primary neuronal cultures.

\section{Discussion}

In the present study, we show for the first time that Ral, its guanine nucleotide exchange factor RalGDS, and PLD2 are each associated with mGluRs. The interaction between group $1 \mathrm{mGluRs}$, Ral, RalGDS, and PLD2 is constitutive and not inducible by agonist treatment. The binding of this novel mGluR-associated complex appears to target class $1 \mathrm{mGluRs}$ for constitutive, agonistindependent internalization. Several other GPCRs, including the cholecystokinin, thrombin, protease-activated receptors and M2 muscarinic acetylcoholine receptors, also exhibit constitutive internalization (Shapiro et al., 1996; Tarasova et al., 1997; Roseberry and Hosey, 1999; Paing et al., 2002), although the details of the mechanism by which these receptors internalize remain to be elucidated. The formation of an mGluR-scaffolded RalGDS/Ral/ PLD2 protein complex function provides a novel alternative adaptor mechanism for GPCR endocytosis that does not appear to require $\beta$-arrestin. a
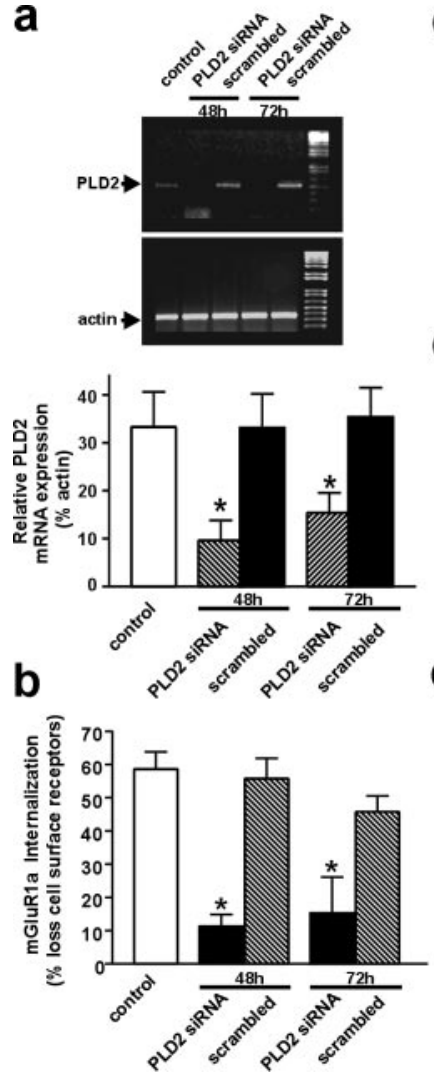

C

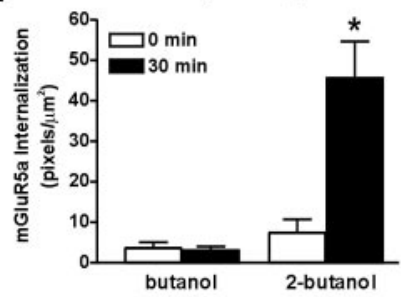

e

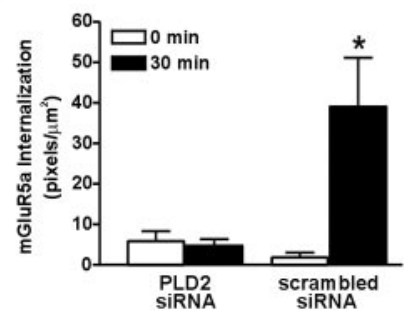

Figure 10. PLD2 activity is required for constitutive mGluR internalization. $a, \mathrm{RT}-\mathrm{PCR}$ analysis of PLD2 mRNA expression in HEK 293 cells either before (control) or after the transfection of cells with $100 \mathrm{~nm}$ of either PLD2 siRNA or scrambled siRNA (scrambled) for 48 and $72 \mathrm{hr}$. RT-PCR of actin mRNA under identical conditions is provided as a control. The bar graph shows the mean $\pm \mathrm{SE}$ for four experiments for PLD2 mRNA expression compared with $\beta$-actin mRNA expression after treatment with PLD2 and scrambled siRNA constructs ${ }^{*} p<0.05$ versus untreated cells. $b$, Effect of cotransfecting $100 \mathrm{~nm}$ of either PLD2 or scrambled siRNA with $1 \mu \mathrm{g}$ of FLAG-mGuR1a plasmid on the constitutive mGluR1a internalization at 48 and $72 \mathrm{hr}$ after transfection. ${ }^{*} p<0.05$ versus cells transfected with FLAG-mGluR1a alone (control). Data are presented as the mean \pm SE of four independent experiments. c, Constitutive FLAG-mGluR1a internalization in HEK 293 cells after the incubation of the cells with and without 1\% 1-butanol and $1 \% 2$-butanol for 30 min at $37^{\circ} \mathrm{C} .{ }^{*} p<0.05$ versus untreated cells transfected with FLAGmGluR1a alone (control). Data are presented as the mean \pm SE of four independent experiments. In $b$ and $c$, internalization was calculated as the percentage of loss of cell surface immunofluorescence after the incubation of primary FLAG antibody-labeled cells for $30 \mathrm{~min}$ at $37^{\circ} \mathrm{C}$ as measured by flow cytometry. $d$, Internalization of Alexa Fluor 555 -conjugated FLAG antibody in cerebellar neurons transfected with FLAG-mGLuR5a and treated with either 1\% 1-butanol or $1 \%$ 2-butanol. Data are presented as the mean \pm SE of 10 independent experiments. ${ }^{*} p<$ 0.05 versus cells maintained on ice. $e$, Internalization of Alexa Fluor 555-conjugated FLAG antibody in cerebellar neurons transfected with both FLAG-mGLu R5a and $100 \mathrm{~nm}$ of either PLD2 or scrambled siRNA. Data are presented as the mean \pm SE of nine independent experiments. ${ }^{*} p<0.05$ versus cells maintained on ice.

Several studies have indicated that the activation of class 1 mGluRs can stimulate PLD activity in vivo (PellegriniGiampietro et al., 1996; Shinomura et al., 2000; Servitja et al., 2003). Although the cellular functions of PLDs remain poorly understood, recent studies have shown that the recruitment of the AP2 adaptor complex is facilitated by phosphatidic acid, the metabolite of PLD activation (Liscovitch and Cantley, 1995; Arneson et al., 1999). Thus, receptor endocytosis may be regulated by GPCR binding to either $\beta$-arrestins or a Ral/PLD2 complex potentially resulting in the subsequent recruitment and/or interaction with components of the AP2 adaptor complex. Consequently, we hypothesize that class 1 mGluRs may function as 
scaffolds for the recruitment of RalGDS, Ral, and PLD2 to promote receptor endocytosis. A previous study suggests that constitutive mGluR5 internalization is mediated by a clathrinindependent mechanism (Fourgeaud et al., 2003). However, we found that both mGluR1a and mGluR5a colocalize with clathrin in HEK 293 cells and that constitutively internalized mGluR1a and mGluR5a are colocalized in the same endocytic vesicles (Fig. 4b) (Dale et al., 2001). This suggests that the Ral/PLD2dependent mechanism for constitutive mGluR endocytosis is likely clathrin mediated, at least in HEK 293 cells. Nevertheless, this does not rule out the possibility that mGluRs either use additional alternative endocytic mechanisms in different cell types or that multiple functionally distinct populations of clathrincoated vesicles may exist (Cao et al., 1998).

Recently, Pula et al. (2004) reported that constitutive mGluRla internalization is suppressed by treating the receptor with inverse agonists, whereas the constitutive endocytosis of mGluR5a is unaffected by inverse agonist treatment (Fourgeaud et al., 2003). Thus, there may be differences between mGluRla and mGluR5a with respect to the contribution of constitutive activity to constitutive endocytosis. However, it is possible that the inverse agonist used to antagonize mGluR5 constitutive internalization may stabilize a conformation of the receptor that reduces spontaneous activity without antagonizing constitutive endocytosis. Consistent with this possibility, there are several examples of GPCR antagonists that promote GPCR internalization in the absence of receptor activity (Roettger et al., 1997; Bhowmick et al., 1998). In the present study, we show that both mGluR1a and mGluR5a interact with Ral and RalGDS and that the endocytosis of both receptors in either neurons or heterologous cell lines is PLD2 dependent. Thus, despite whatever mechanism might lead to the activation of the Ral/RalGDS/PLD2 complex, this complex is essential for the constitutive endocytosis of both receptors.

In addition to regulating endocytosis, Ral plays an important role in regulating exocytosis, as a consequence of its association with the exocyst complex (Feig, 2003). Thus, although we have only assessed the role of Ral and PLD2 in the regulation of the internalization of cell surface mGluRla and mGluR5a, it is possible that Ral may also play a role in regulating the recycling of constitutively endocytosed mGluRs back to the plasma membrane. This might provide an elegant mechanism by which Ral activity might modulate the relative distribution of class 1 mGluRs between membrane compartments. Future studies will be required to determine whether Ral might contribute to mGluR recycling and/or potentially mGluR downregulation.

Identical to what we observe here for class $1 \mathrm{mGluRs}$, ionotropic glutamate AMPA receptors are also constitutively internalized (Man et al., 2000). The trafficking of NMDA receptors between the plasma membrane and intracellular synaptic compartment plays an essential role in regulating synaptic activity (Carroll and Zukin, 2002). Recent evidence suggests that depolarization-induced Homerla protein upregulation may contribute to mGluR1-dependent long-term potentiation by antagonizing the turnover of cell surface mGluRs (Minami et al., 2003). Thus, constitutive endocytosis of mGluRs in neurons may also provide a dynamic mechanism by which mGluR signaling is modulated via interactions with other proteins that are components of the postsynaptic density.

PLD2 activity also regulates $\mu$-opioid receptor and angiotensin II type 1A receptor internalization (Du et al., 2004). PLD2 has also been identified by yeast two-hybrid to associate with the $\mu$-opioid receptor C-tail (Koch et al., 2003, 2004). Our results establish a general role for PLD2 in the regulation of GPCR endocytosis. However, unlike what was reported in a previous study with the $\mu$-opioid receptor (Koch et al., 2003), we do not observe a loss of PLD2 binding to mGluR1a and mGluR5a after agonist activation. Rather, we observe that both Ral and PLD2 form stable complexes with mGluRs and that both Ral and PLD2 are localized in an mGluR-dependent manner to endocytic vesicles. To our knowledge, our data provide the first evidence linking Ral activity to the regulation of GPCR internalization. The Ral/ PLD2-dependent regulation of class $1 \mathrm{mGluR}$ internalization is not attributable to a nonspecific attenuation of receptor endocytosis because $\beta_{2} \mathrm{AR}$ internalization is not attenuated by either Ral mutant or PLD2 overexpression. Thus, it now appears that the targeting of GPCRs for internalization is regulated by both $\beta$-arrestin- and Ral/PLD2-dependent mechanisms. Although $\beta$-arrestins assert a predominant role in regulating the agoniststimulated endocytosis of many GPCRs, our data indicate an alternative Ral/PLD2 endocytic mechanism, essential for constitutive mGluR internalization, may underlie the $\beta$-arrestinindependent endocytic mechanism that has been reported to contribute to the endocytosis of many GPCRs. The role of Ral and PLD2 binding to GPCRs, EGF, transferrin, and activin receptors and the regulation of their endocytosis suggests that Ral and PLD2 may act as proximal adaptor proteins that when activated target receptors for endocytosis.

\section{References}

Arneson LS, Kunz J, Anderson RA, Traub LM (1999) Coupled inositide phosphorylation and phospholipase D activation initiates clathrin-coat assembly on lysosomes. J Biol Chem 274:17794-17805.

Bhattacharya M, Anborgh PH, Babwah AV, Dale LB, Dobransky T, Benovic JL, Feldman RD, Verdi JM, Rylett RJ, Ferguson SSG (2002) $\beta$-Arrestins regulate a Ral-GDS Ral effector pathway that mediates cytoskeletal reorganization. Nat Cell Biol 4:547-555.

Bhowmick N, Narayan P, Puett D (1998) The endothelin subtype A receptor undergoes agonist- and antagonist-mediated internalization in the absence of signaling. Endocrinology 139:3185-3192.

Cao TT, Mays RW, von Zastrow M (1998) Regulated endocytosis of G-protein-coupled receptors by a biochemically and functionally distinct subpopulation of clathrin-coated pits. J Biol Chem 273:24592-24602.

Carroll RC, Zukin RS (2002) NMDA-receptor trafficking and targeting: implications for synaptic transmission and plasticity. Trends Neurosci 25:571-577.

Chavrier P, Goud B (1999) The role of ARF and Rab GTPases in membrane transport. Curr Opin Cell Biol 11:466-475.

Claing A, Chen W, Miller WE, Vitale N, Moss J, Premont RT, Lefkowitz RJ (2001) $\beta$-Arrestin-mediated ADP-ribosylation factor 6 activation and $\beta_{2}$-adrenergic receptor endocytosis. J Biol Chem 276:42509-42513.

Craven SE, El-Husseini AE, Bredt DS (1999) Synaptic targeting of the postsynaptic density protein PSD-95 mediated by lipid and protein motifs. Neuron 22:497-509.

Dale LB, Bhattacharya M, Anborgh PH, Murdoch B, Bhatia M, Nakanishi S, Ferguson SSG (2000) G protein-coupled receptor kinase mediated desensitization of metabotropic glutamate receptor $1 \alpha$ protects against cell death. J Biol Chem 275:38213-38220.

Dale LB, Bhattacharya M, Seachrist JL, Anborgh PH, Ferguson SSG (2001) Agonist-stimulated and tonic internalization of metabotropic glutamate receptor 1a in human embryonic kidney 293 cells: agonist-stimulated endocytosis is $\beta$-arrestin1 isoform-specific. Mol Pharmacol 60:1243-1253.

Dale LB, Babwah AV, Ferguson SSG (2002) Mechanisms of metabotropic glutamate receptor desensitization: role in the patterning of effector enzyme activation. Neurochem Int 41:319-326.

Dale LB, Seachrist JL, Babwah AV, Ferguson SSG (2004) Regulation of angiotensin II 1A receptor intracellular retention, degradation and recycling by Rab5, Rab7 and Rab11 GTPases. J Biol Chem 279:13110-13118.

De Camilli P, Emr SD, McPherson PS, Novick P (1996) Phosphoinositides as regulators in membrane traffic. Science 271:1533-1539.

Du G, Huang P, Liang BT, Frohman MA (2004) Phospholipase D2 localizes 
to the plasma membrane and regulates angiotensin II receptor endocytosis. Mol Biol Cell 15:1024-1030.

Feig LA (2003) Ral-GTPases: approaching their 15 minutes of fame. Trends Cell Biol 13:419-425.

Ferguson SSG (2001) Evolving concepts in G protein-coupled receptor endocytosis: the role in receptor desensitization and signaling. Pharmacol Rev 53:1-24.

Ferguson SSG, Downey 3rd WE, Colapietro AM, Barak LS, Menard L, Caron MG (1996) Role of $\beta$-arrestin in mediating agonist-promoted G protein-coupled receptor internalization. Science 271:363-366.

Fourgeaud L, Bessis AS, Rossignol F, Pin JP, Olivo-Marin JC, Hemar A (2003) The metabotropic glutamate receptor mGluR5 is endocytosed by a clathrin-independent pathway. J Biol Chem 278:12222-12230.

Goodman Jr OB, Krupnick JG, Santini F, Gurevich VV, Penn RB, Gagnon AW, Keen JH, Benovic JL (1996) $\beta$-Arrestin acts as a clathrin adaptor in endocytosis of the $\beta_{2}$-adrenergic receptor. Nature 383:447-450.

Hanson JE, Smith Y (1999) Class I metabotropic glutamate receptors at GABAergic synapses in monkeys. J Neurosci 19:6488-6496.

Jullien-Flores V, Mahe Y, Mirey G, Leprince C, Meunier-Bisceuil B, Sorkin A, Camonis JH (2000) RLIP76, an effector of the GTPase Ral, interacts with the AP2 complex: involvement of the Ral pathway in receptor endocytosis. J Cell Sci 113:2837-2844.

Kim JH, Lee SD, Han JM, Lee TG, Kim Y, Park JB, Lambeth JD, Suh PG, Ryu SH (1998) Activation of phospholipase D1 by direct interaction with ADP-ribosylation factor 1 and RalA. FEBS Lett 430:231-235.

Koch T, Brandenburg LO, Schulz S, Liang Y, Klein J, Hollt V (2003) ADPribosylation factor-dependent phospholipase D2 activation is required for agonist-induced $\mu$-opioid receptor endocytosis. J Biol Chem 278:9979-9985.

Koch T, Brandenburg LO, Liang Y, Schulz S, Beyer A, Schroder H, Hollt V (2004) Phospholipase D2 modulates agonist-induced $\mu$-opioid receptor desensitization and resensitization. J Neurochem 88:680-688.

Laporte SA, Oakley RH, Zhang J, Holt JA, Ferguson SSG, Caron MG, Barak LS (1999) The $\beta_{2}$-adrenergic receptor/ $\beta$ arrestin complex recruits the clathrin adaptor AP-2 during endocytosis. Proc Natl Acad Sci USA 96:3712-3717.

Liscovitch M, Cantley LC (1995) Signal transduction and membrane traffic: the PITP/phosphoinositide connection. Cell 81:659-662.

Luo JQ, Liu X, Frankel P, Rotunda T, Ramos M, Flom J, Jiang H, Feig LA, Morris AJ, Kahn RA, Foster DA (1998) Functional association between Arf and RalA in active phospholipase D complex. Proc Natl Acad Sci USA 95:3632-3637.

Man HY, Lin JW, Ju WH, Ahmadian G, Liu L, Becker LE, Sheng M, Wang YT (2000) Regulation of AMPA receptor-mediated synaptic transmission by clathrin-dependent receptor internalization. Neuron 25:649-662.

Matsuzaki T, Hanai S, Kishi H, Liu Z, Bao Y, Kikuchi A, Tsuchida K, Sugino H (2002) Regulation of endocytosis of activin type II receptors by a novel PDZ protein through Ral/Ral-binding protein 1-dependent pathway. J Biol Chem 277:19008-19018.

Minami I, Kengaku M, Smitt PS, Shigemoto R, Hirano T (2003) Long-term potentiation of mGluR1 activity by depolarization-induced Homerla in mouse cerebellar Purkinje neurons. Eur J Neurosci 17:1023-1032.
Morris AJ, Frohman MA, Engebrecht J (1997) Measurement of phospholipase D activity. Anal Biochem 252:1-9.

Nakanishi S (1994) Metabotropic glutamate receptors: synaptic transmission, modulation, and plasticity. Neuron 13:1031-1037.

Nakashima S, Morinaka K, Koyama S, Ikeda M, Kishida M, Okawa K, Iwamatsu A, Kishida S, Kikuchi A (1999) Small G protein Ral and its downstream molecules regulate endocytosis of EGF and insulin receptors. EMBO J 18:3629-3642.

Paing MM, Stutts AB, Kohout TA, Lefkowitz RJ, Trejo J (2002) $\beta$-Arrestins regulate protease-activated receptor-1 desensitization but not internalization or down-regulation. J Biol Chem 277:1292-1300.

Pellegrini-Giampietro DE, Torregrossa SA, Moroni F (1996) Pharmacological characterization of metabotropic glutamate receptors coupled to phospholipase D in the rat hippocampus. Br J Pharmacol 118:1035-1043.

Premont RT, Inglese J, Lefkowitz RJ (1995) Protein kinases that phosphorylate activated G protein-coupled receptors. FASEB J 9:175-182.

Pula G, Mundell SJ, Roberts PJ, Kelly E (2004) Agonist-independent internalization of metabotropic glutamate receptor 1a is arrestin- and clathrindependent and suppressed by receptor inverse agonists. J Neurochem 89:1009-1020.

Roettger BF, Ghanekar D, Rao R, Toledo C, Yingling J, Pinon D, Miller LJ (1997) Antagonist-stimulated internalization of the G protein-coupled cholecystokinin receptor. Mol Pharmacol 51:357-362.

Roseberry AG, Hosey MM (1999) Trafficking of M(2) muscarinic acetylcholine receptors. J Biol Chem 274:33671-33676.

Sallese M, Salvatore L, D’Urbano E, Sala G, Storto M, Launey T, Nicoletti F, Knopfel T, De Blasi A (2000) The G-protein-coupled receptor kinase GRK4 mediates homologous desensitization of metabotropic glutamate receptor 1. FASEB J 14:2569-2580.

Servitja JM, Masgrau R, Pardo R, Sarri E, von Eichel-Streiber C, Gutkind JS, Picatoste F (2003) Metabotropic glutamate receptors activate phospholipase D in astrocytes through a protein kinase C-dependent and Rhoindependent pathway. Neuropharmacology 44:171-180.

Shapiro MJ, Trejo J, Zeng D, Coughlin SR (1996) Role of the thrombin receptor's cytoplasmic tail in intracellular trafficking. Distinct determinants for agonist-triggered versus tonic internalization and intracellular localization. J Biol Chem 271:32874-32880.

Shen Y, Xu L, Foster DA (2001) Role for phospholipase D in receptormediated endocytosis. Mol Cell Biol 21:595-602.

Shinomura T, del Rio E, Breen KC, Downes CP, McLaughlin M (2000) Activation of phospholipase $\mathrm{D}$ by metabotropic glutamate receptor agonists in rat cerebrocortical synaptosomes. Br J Pharmacol 131:1011-1018.

Slaaby R, Jensen T, Hansen HS, Frohman MA, Seedorf K (1998) PLD2 complexes with the EGF receptor and undergoes tyrosine phosphorylation at a single site upon agonist stimulation. J Biol Chem 273:33722-33727.

Tarasova NI, Stauber RH, Choi JK, Hudson EA, Czerwinski G, Miller JL, Pavlakis GN, Michejda CJ, Wank SA (1997) Visualization of G proteincoupled receptor trafficking with the aid of the green fluorescent protein. Endocytosis and recycling of cholecystokinin receptor type A. J Biol Chem 272:14817-14824. 